
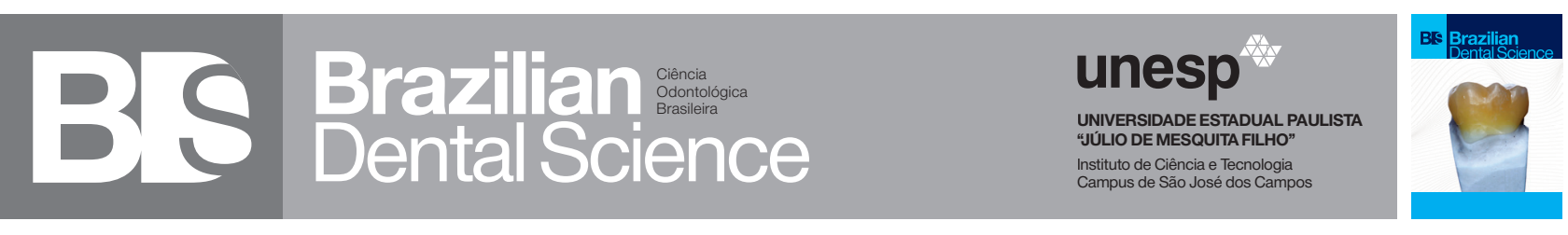

\title{
Influence of surface treatments in flexural strength and superficial topography of a lithium disilicate ceramic
}

Influência dos tratamentos de superfície na resistência à flexão e na topografia superficial de uma cerâmica de dissilicato de lítio

Natália Rivoli ROSSI ${ }^{1}$, Tabata do Prado SATO ${ }^{1}$, Caroline Cotes MARINHO ${ }^{1}$, Vanessa da Cruz MACEDO ${ }^{1}$, Tarcísio José de Arruda PAES JUNIOR ${ }^{2}$, Estevão Tomomitsu KIMPARA ${ }^{2}$

1 - Univ Estadual Paulista (Unesp) - Institute of Science and Technology, São José dos Campos - SP - Brazil

2 - Univ Estadual Paulista (Unesp) - Institute of Science and Technology, São José dos Campos - Department of Dental Materials and Prosthodontics - São José dos Campos - SP - Brazil.

\section{ABSTRACT}

Objective: The aim of the study was to evaluate the influence of different surface post-etching treatments in flexural strength, contact angle and surface roughness of a lithium disilicate ceramic. Material and Methods: 60 bars $(16 \times 2 \times 4 \mathrm{~mm})$ were divided in six groups $(n=10)$ : $C$, no treatment; HF, hydrofluoric acid for $20 \mathrm{~s}$ (HF) + washing (60 s), drying (30s); HFL, HF + washing (60 s), drying (30 s) and luting; HFNL, HF + washing (60 s) + neutralization with sodium bicarbonate (SB) for $40 \mathrm{~s}+$ washing (5s), drying (30 s) and luting; HFUL, HF + washing (60 s) + ultrasonic bath (UB) for 4 min, drying (30 s) and luting; HFNUL, HF + washing (60 s) + SB (40 s) + UB (4 min) and luting. The bars were submitted to three-points flexural strength test. 25 ceramic blocks ( $12 \times 7 \times 7 \mathrm{~mm}$ ) were divided into five groups $(n=5)$ to evaluate roughness and contact angle $C$ - no treatment; HF - HF ; HFU - HF and UB for 5 min ; HFN - HF and SB; HFNU - HF, UB and SB. A scanning electron microscope (SEM) showed the surface of the samples. ANOVA one-way statistical analysis was done for comparison of results. Results: There was no statistical difference for flexural strength (p-value $=0.15$ ) and for surface roughness (p-valor $=0.15$ ). However, it was obtained statistically significant difference for contact angle ( $\mathrm{p}$-valor $=0.00$ ). SEM images showed precipitates after the acid etching, which were removed by post-etching treatments. Conclusion: It can be concluded that the different post-etching surface treatments did not increase the flexural strength, surface roughness, but it influenced the ceramic wetting and SEM images.

\section{KEYWORDS}

Contact angle; Hydrofluoric acid; Scanning electron microscope; Surface roughness; Ultrasonic bath; lithium disilicate.

\section{RESUMO}

Objetivo: O objetivo do estudo foi avaliar a influência de diferentes tratamentos pós-condicionamento na resistência à flexão, ângulo de contato e rugosidade superficial de uma cerâmica de dissilicato de lítio. Material e Métodos: 60 barras $(16 \times 2 \times 4 \mathrm{~mm})$ foram divididas em seis grupos $(\mathrm{n}=10)$ : C, sem tratamento; HF, ácido fluorídrico durante $20 \mathrm{~s} \mathrm{(HF)} \mathrm{+}$ lavagem (60 s), secagem (30 s); HFL, lavagem com HF + (60 s), secagem (30 s) e cimentação; HFNL, HF + lavagem (60 s) + neutralização com bicarbonato de sódio (SB) por $40 \mathrm{~s}$ + lavagem (5s), secagem (30 s) e cimentação; HFUL, HF + lavagem (60 s) + banho ultrassônico (UB) por 4 min, secagem (30 s) e cimentação; HFNUL, HF + lavagem (60 s) + SB (40 s) + UB (4 min) e cimentação. As barras foram submetidas ao teste de resistência à flexão de três pontos. 25 blocos cerâmicos $(12 \times 7 \times 7 \mathrm{~mm})$ foram divididos em cinco grupos $(n=5)$ para avaliação da rugosidade superficial e ângulo de contato C - sem tratamento; HF - HF; HFU - HF e UB por 5 min; HFN - HF e SB; HFNU - HF, UB e SB. Um microscópio eletrônico de varredura (MEV) foi utilizado para análise da superfície das amostras. A análise estatística unidirecional ANOVA-um fator foi realizada para comparação dos resultados. Resultados: Não houve diferença estatística para a resistência à flexão (p-valor $=0,15)$ e para a rugosidade superficial ( $\mathrm{p}$-valor $=0,15)$. No entanto, obteve-se diferença estatisticamente significante para o ângulo de contato ( $\mathrm{p}$-valor $=0,00$ ). Imagens de microscopia eletrônica de varredura mostraram a formação de precipitados após o ataque ácido, que foram removidos pelos tratamentos pós-condicionamento. Conclusão: Pode-se concluir que os diferentes tratamentos de superfície pós-condicionamento não aumentaram a resistência à flexão, rugosidade da superfície, mas influenciaram na molhabilidade da cerâmica e nas imagens em MEV.

\section{PALAVRAS-CHAVE}

Ângulo de contato; Ácido fluorídrico; Microscópio eletrônico de varredura; Rugosidade superficial; Banho ultrassônico; Dissilicato de lítio. 


\section{INTRODUCTION}

$\mathrm{L}$

ithium disilicate ceramics are used for metalfree prosthesis when it needs adequate strength. The crystals of lithium disilicate were displayed in an enlaced vitreous pattern which prevents internal crack spreading. Thus, it is possible to match great aesthetics and mechanical properties, such as flexural strength, for this ceramic system [1].

Ceramic materials can be veneered and also manufactured by pressed methods or by CAD/CAM system. CAD/CAM system consists in drawing the prosthetic structure in a computer (Computer Aided Design) which is followed by confection in a milling machine (Computer Aided Manufacturing). High technology CAD/CAM system is based in three central components. First, it is necessary to scan the prepared tooth, then, it will be possible to draw the prosthetic restauration in a computer software (CAD). At last, the draw of the restauration can be milled in a machine (CAM). The system reduces restauration inaccuracies and grants better results compared to cast technique [2].

Surface treatments are very important protocols because they increase adhesion property which improves the bonding between cement and tooth. Acid etching with hydrofluoric acid (HF) is one of the most established protocols for ceramics. HF etching creates and maintains chemical and mechanical adhesion between ceramics and resin materials because creates microporosities on the surface of the ceramic, which change wetting property and promote a higher contact between resin cement and ceramic surface [3]. The use of $\mathrm{HF}$ on the surface of ceramic increases contact surface because it creates microretentions, providing a higher resin/ceramic bond. The longevity of a ceramic restauration can be longer when etching time and $\mathrm{HF}$ concentration are changed [4] because HF acid attacks the glassy phase of acid-sensitive ceramic (silica based - SiO2), exposing silica oxides and yielding topographic changes for increased micromechanical retention and chemical bonding with a silane coupling agent. Also higher etching time increases bond strength between resin/ceramic, because it promotes a higher average surface roughness compared to the etching time recommended by the fabricant. Furthermore, it produces deeper microretentive surface than it would be reached by the fabricant recommendation time. The microretentions can be seen by scanning electron microscope (SEM) [5].

Acid etching is a reliable surface treatment, especially when followed by silanization [6]. Silane coupling agents are bifunctional molecules responsible to create covalent bonds between ceramics and resin cement. In vitro studies proved that silane coupling agents are effective to increase the resin/ceramic adhesion [7]. Although acid etching and silanization processes before luting increase bond strength, etching process with HF corrodes ceramic surface creating subproducts and precipitates, which obstruct the microporosities and impairs adhesive resin infiltration. Some authors [8] verified an increase in resin/ceramic bond strength after post-etching cleaning and residue elimination, while others $[9,10]$ did not find differences between post-etching cleaned and uncleaned samples. One of the cleaning methods is the ultrasonic bath which removes post-etch precipitates. As a result, surface become permeable which raises the bonding between the substrates $[11,12]$.

In order to create a more reactive surface, a cleaning method can be associated with a neutralization process of $\mathrm{HF}$ precipitates. The combination of these methods increases adhesive bond strength between resin cement and feldspathic ceramic [5].

Topographical analysis is performed by scanning electron microscope (SEM), by contact profilometer and by goniometer. The images of the post-etching ceramic surface treatment generated by a SEM could show the effects of acid etching time and post-etching 
cleaning $[10,11]$. Surface roughness can be measured by a contact profilometer, which gives the average surface roughness ( $\mathrm{Ra}$ ) of the samples, making the comparison of the results possible [13]. Also, it is one of the majors tests that can describe the effectivity of pre-treatment procedures [14]. Contact angle and surface ceramic wetting are evaluated using a goniometer [15]. Surface roughness affects the wettability of the ceramic surface and thereby the subsequently applied silanes coupling agent and resin composite [16].

Flexural strength is determined by the three-points flexural test performed in a universal test machine in constant wetting. Strength is described as the maximum stress that can be applied to a material before it breaks, and this is used as a mechanical property to identify the clinical success of materials [17].

It is known that etching with HF acid changes material surface, altering wetting [3], and average surface roughness [5], promoting higher contact between resin/ ceramic surfaces [3], and producing deeper microretentions [5] compared to non-etched ceramic. Although some studies demonstrated higher bond strength with the association of neutralization and ultrasonic bath [5] in comparison to samples which did not receive these surface treatments, it is still not clear the effectiveness of neutralization process and how the precipitates elimination interferes in the mechanic properties of the ceramic. Therefore, the aim of this study was to evaluate the effects of different surface post-etching treatments in flexural strength, on superficial roughness and on contact angle of a lithium disilicate ceramic processed by CAD/CAM system.

\section{MATERIAL AND METHODS}

Emax CAD ceramic blocks (Ivoclar Vivadent, Schaan, Liechtenstein) were sectioned in standardized samples with the following dimensions $16 \times 2 \times 4 \mathrm{~mm}$ and $12 \times$ $7 \times 7 \mathrm{~mm}$.
All specimens were polished by a grinder polisher (Buehler, Ecomet 250, Grinder polisher, USA) with constant water refrigeration, using sandpapers with different granulation, 280, 800 and 1200 , reaching the desired dimensions. The specimens were also cleaned in an ultrasonic bath with distilled water for five minutes. The crystallization of the bars was performed in an oven for ceramics (P300, Ivoclar Vivadent, Schaan, Liechtenstein) at maximum temperature of $840{ }^{\circ} \mathrm{C}\left(1544{ }^{\circ} \mathrm{F}\right)$.

\section{Surface treatments}

\begin{tabular}{|c|} 
Hydrofluoric etch $5 \%$ for $20 \mathrm{C}$ \\
Ultrasonic bath (UB) for 5 minutes \\
\hline Neutralization with sodium bicarbonate (SB) for $40 \mathrm{~S}$ \\
\hline Silane agent for $60 \mathrm{~S}$ \\
\hline Resin cement (Variolink II) photo-activated for $40 \mathrm{~S}$
\end{tabular}

All specimens were etched by $5 \% \mathrm{HF}$ for $20 \mathrm{~s}$. After the acid etching, the specimens with dimension $16 \times 2 \times 4 \mathrm{~mm}$ were washed by air-water spray for $60 \mathrm{~s}$ and dried by air spray for $30 \mathrm{~s}$. Specimens with dimension 12 x 7 x $7 \mathrm{~mm}$ were washed by air-water spray for $20 \mathrm{~s}$.

For luting process, the specimens received one layer of silane agent, and then, after $60 \mathrm{~s}$ drying it, were lutted by resin cement, following the manufacturers' instructions. A micrometer was necessary to standardize the cement superficial layer, and the specimens were isolated using polyester strips.

For neutralization process, the specimens were submerged in supersaturated solution of sodium bicarbonate for $40 \mathrm{~s}$ - double of the etching time $[5,8]$. For ultrasonic bath ((Vitasonic, Vita Zanhfabrik, Bad Sackingen, Germany), the specimens were submerged during 5 minutes in distilled water $(100 \mathrm{ml})$. 


\section{Surface roughness and contact angle analysis}

For the surface roughness and contact angle analysis, 25 ceramic blocks (12 x 7 x 7 $\mathrm{mm}$ ) were randomly split in five groups ( $\mathrm{n}=$ 5 ), with the following surface treatments:

\begin{tabular}{|c|c|}
\hline Groups & Surface treaments \\
\hline C & No treatment; \\
\hline HF & HF (20 s) + washing (20 s); \\
\hline HFU & $\begin{array}{l}\mathrm{HF}(20 \mathrm{~s})+\text { washing }(20 \mathrm{~s})+\text { ultrasonic bath for } 5 \text { minutes } \\
\text { (UB); }\end{array}$ \\
\hline HFN & $\begin{array}{l}H F(20 \mathrm{~s})+\text { washing }(20 \mathrm{~s})+\text { neutralization with } \mathrm{SB}+ \\
\text { washing }(5 \mathrm{~s}) ;\end{array}$ \\
\hline HFNU & $\begin{array}{c}\mathrm{HF}(20 \mathrm{~s})+\text { washing }(20 \mathrm{~s})+\text { neutralization with } \mathrm{SB}+\mathrm{UB}+ \\
\text { washing }(5 \mathrm{~s}) ;\end{array}$ \\
\hline
\end{tabular}

After surface treatments, each ceramic block received superficial roughness analyses (Ra, $\mu \mathrm{m}$ ) using a contact profilometer (Mitutoyo, SJ400, Kanagawa, Japan), with Iso 1997 parameters, and length measurement of $3 \mathrm{~mm}$. Ra value was traced by a surface measurement instrument which describes the average superficial roughness of a specimen. Five measurements were made in alleatory spots of each specimen, and the average was used to obtain the Ra value for each specimen. The instrument was calibrated before the measurement in a reference block with $\mathrm{Ra}$ value $2.94 \mu \mathrm{m}$.

Under controlled temperature $\left(25^{\circ} \mathrm{C}\right)$, the contact angle analysis was made by a goniometer (Theta Lite model, Attension, Biolin Scientific, Espoo, Finland) connected to a computer software (One Attension) for measuring the contact angle and surface energy. A drop of distilled water was put over the ceramic surface using a syringe, and after ten seconds, the contact angle was measured [15].

The obtained values of $\mathrm{Ra}(\mu \mathrm{m})$ and contact angle were submitted to a descriptive statistical analysis (average and standard deviation). The One-way ANOVA test was used to evaluate data in the softwares: MINITAB
(Minitab, version 16.1, 2010) and PRISM (versão 5.0, GraphPad, 2009).

Five extra ceramic blocks were made according to the mentioned methods, and were split between the five groups of surface treatment. Then, the specimens were sputtered coated with gold (EMITECH SC7620, Sputter Coater) with thickness $8 \mathrm{~nm}$ for $120 \mathrm{~s}$ at 12 $\mathrm{mA}$. Then, it was possible to analyze the ceramic surface in a SEM (INSPECT, S50, FEI, Czech Republic). The image of each group was taken in a 5000x extension. The microscope operated in an acceleration voltage of $25 \mathrm{Kv}$.

\section{1 - Flexural strength test:}

For the flexural strength test, sixty ceramic bars (16 x $2 \times 4 \mathrm{~mm})$ were randomly split in six groups $(n=10)$, with the following surface treatments:

\begin{tabular}{|c|c|}
\hline Groups & Surface treaments \\
\hline C & No treatment; \\
\hline HF & $\begin{array}{l}\text { Hydrofluoric acid etching (HF) for } 20 \mathrm{~s}+\text { air-water spray } \\
\text { washing (60 s), air drying ( } 30 \mathrm{~s}) \text {; }\end{array}$ \\
\hline HFL & $\begin{array}{l}\mathrm{HF}(20 \mathrm{~s})+\text { air-water spray washing (60 s), air drying (30 s) } \\
\text { and luting; }\end{array}$ \\
\hline HFNL & $\begin{array}{l}\mathrm{HF}(20 \mathrm{~s})+\text { air-water spray washing }(60 \mathrm{~s})+\text { neutralization } \\
\text { with SB }(40 \mathrm{~s})+\text { air-water spray washing }(5 \mathrm{~s}) \text { + air drying } \\
\text { (30 s) and luting; }\end{array}$ \\
\hline HFUL & $\begin{array}{l}\text { HF (20 s) + air-water spray washing (60 s) + UB (5 min) + } \\
\text { air drying (30 s) and luting; }\end{array}$ \\
\hline HFNUL & $\begin{array}{c}\mathrm{HF}(20 \mathrm{~s})+\text { air-water spray washing }(60 \mathrm{~s})+\text { neutralization } \\
\text { with SB (40 s) + UB (4 min) and luting. }\end{array}$ \\
\hline
\end{tabular}

For application of luting agent a resin cement (Variolink II, Ivoclar Ivoclar, Schaan, Liechestein) were applied on the ceramic bars using equally parts of base and catalyst and mixed for $10 \mathrm{~s}$. The bars were kept in a constant charge of $750 \mathrm{~g}$ to standardize cement layer. The LED photo activation device (RadiiCal Polimerize, SDI, Victoria, Australia) with energy of $1,200 \mathrm{~mW} / \mathrm{cm}^{2}$, was photoactivated on each face of the specimen for $2 \mathrm{~s}$ to make easier to remove the cement excess. Then, the luting agent were photo-activated for $40 \mathrm{~s}$. After luting process, the specimens were 
stored in distilled water in $37^{\circ} \mathrm{C}$ for $24 \mathrm{~h}$. Each bar was set in a metallic device made for the flexural strength test. Each of the specimens was supported upon two cylinders $(2 \mathrm{~mm}$ of diameter) with $32 \mathrm{~mm}$ of distance between each other. Only the specimen ends were used to be a support, so the central zone was free to receive the load. The load was applied on the opposite side of luting surface by a rod with cylindrical active tip ( $2 \mathrm{~mm}$ of diameter) coupled to a universal testing machine (EMIC DL 1000, São José dos Pinhais - PR, Brazil), submitting the specimen to compression $(\mathrm{v}=1$ $\mathrm{mm} / \mathrm{min}$, 10kgf of load cell) until catastrophic fail. The mechanical test was performed in a $100 \%$ moist environment (immersed in distilled water), at $37^{\circ} \mathrm{C}$, in order to increase the cracks propagation speed.

To calculate flexural strength (MPa), the following mathematical formula was used: 3PL/2WT2, which: $\mathrm{P}$ is the recorded maximum applied load in the moment that occurred the fracture; L, distance between the holders; $\mathrm{W}$, specimen width $(4 \mathrm{~mm})$ and $\mathrm{T}$, specimen thickness $(2 \mathrm{~mm})$. After the mechanical test, each specimen of the six different groups was evaluated by SEM, analyzing the morphology on the fractured area. This analysis showed superficial and morphological characteristics of the flaws (cracks, pores and precipitates) after different surface treatments and illustrated the failure mode and origin.

\section{RESULTS}

\section{angle analysis}

1 - Surface roughness and contact

There are no statistically significant differences between groups for the average roughness $(\mathrm{Ra})$ ( $\mathrm{p}$-valor $=0.15)$, showed in the Table 1 . The groups obtained statistically significant differences for the contact angle (p-valor $=0.00)$, showed in the Table 2 . Tukey Test showed that $\mathrm{C}$ group had the highest contact angle, and it was statistically significant when compared with other groups. HF group had the lowest contact angle, and it was statistically different of HFNU group.

Table 1 - Mean value and standard deviations for average roughness $(\mathrm{Ra})$

\begin{tabular}{|cc|}
\multicolumn{2}{c}{ Average roughness (Ra) } \\
\hline Groups & $\begin{array}{c}\text { Mean value (standard } \\
\text { deviation) }\end{array}$ \\
\hline C & $0.08(0.02)$ \\
\hline HF & $0.09(0.04)$ \\
\hline HFU & $0.11(0.03)$ \\
\hline HFN & $0.19(0.10)$ \\
\hline HFNU & $0.10(0.03)$ \\
\hline
\end{tabular}

Table 2 - Mean value and standard deviations for contact angle $(p$-value $=0,00)$

\begin{tabular}{|ccc|}
\hline Contact Angle & \\
\hline Groups & $\begin{array}{c}\text { Mean value (stan- } \\
\text { dard deviation) }\end{array}$ & Tukey Test \\
\hline C & $64.12(5.479)$ & A \\
\hline HF & $37.70(2.766)$ & D \\
\hline HFU & $38.25(2.227)$ & CD \\
\hline HFN & $41.17(3.956)$ & BCD \\
\hline HFNU & $46.75(5.899)$ & BC \\
\hline
\end{tabular}

SEM images showed the ceramic surface of the blocks with different surface treatments, in the Figure 1. It can be seen that after HF acid etching, precipitates were created on the ceramic surface, and then, were removed after surface cleaning methods. 

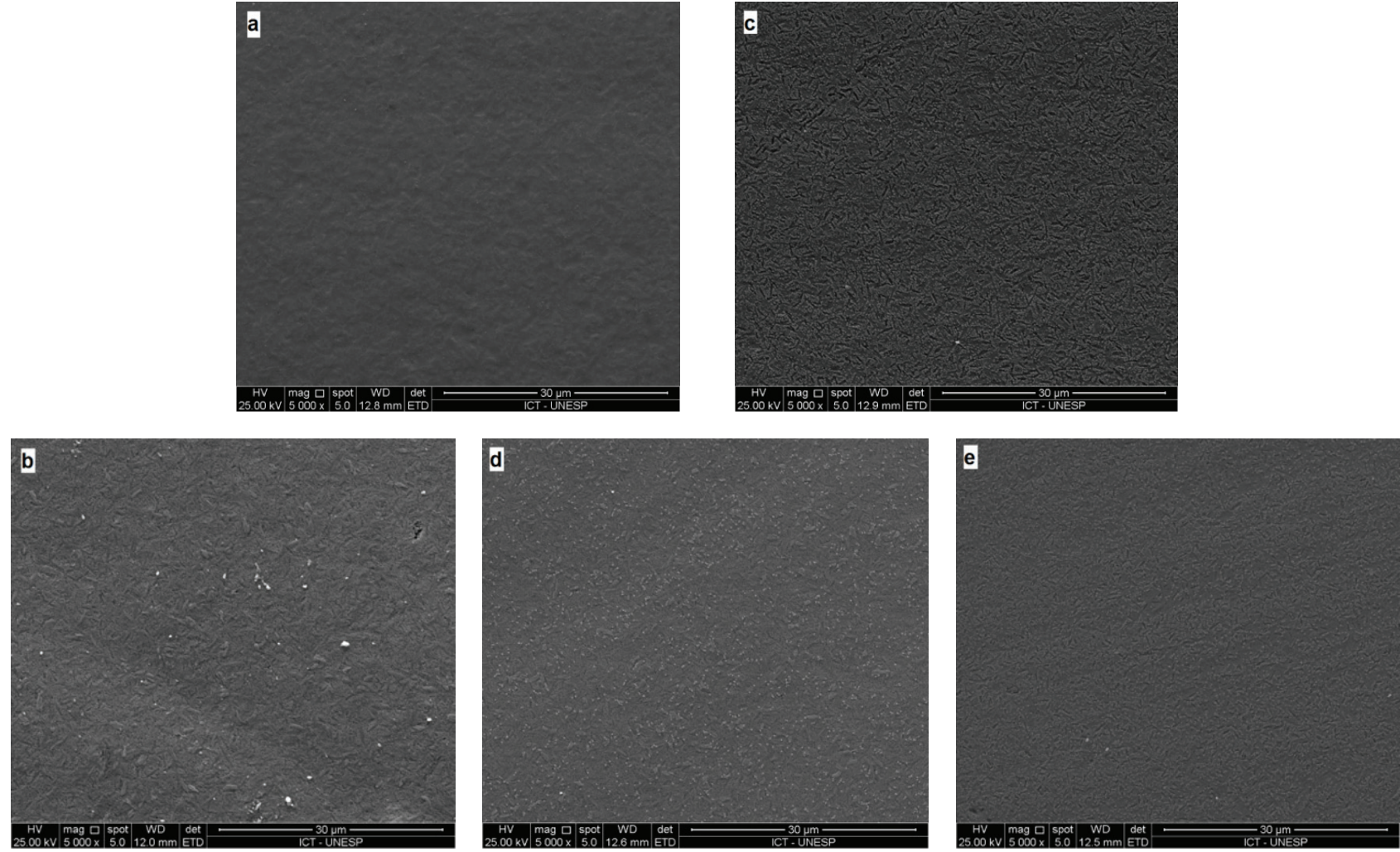

Figure 1 - Indicate the precipitates in the image in which: a) Control; b) HF; c) HFU; d) HFN; e) HFNU.

\section{2 - Flexural strength test}

There were no statistically significant differences for the flexural strength test (p-valor $=0.375$ ). The mean value and standard deviations can be seen in the Table 3 .

Table 3 - Mean value and standard deviations for flexural strength (MPa)

\begin{tabular}{|cc}
\multicolumn{2}{c}{ Flexural Strength $(\mathrm{MPa})$} \\
\hline Groups & $\begin{array}{c}\text { Mean value } \\
\text { (standard deviation) }\end{array}$ \\
\hline C & $318.11(54.63)$ \\
\hline HF & $298.69(37.02)$ \\
\hline HFL & $323.98(49.81)$ \\
\hline HFNL & $318.97(47.56)$ \\
\hline HFUL & $347.84(36.20)$ \\
\hline HFNUL & $307.25(50.75)$ \\
\hline
\end{tabular}

\section{CONCLUSION}

Theflexural strength and surface roughness were not affected by the used treatments, although SEM images showed precipitates after the acid etching and its removal by post-etching treatments. The acid etching improves the ceramic wetting.

Acid etching creates irregular pores, increases surface roughness and attack lithium disilicate ceramics surface. However, in several studies [5, 7-12,15] after acid etching, precipitates were formed on the ceramic surface, remaining inside the surface pores, preventing the penetration of the resin cement, and decreasing the adhesion between substrates [12].

Some authors said that acid precipitates formed after acid etching can be removed [5,7- 
12]. Examining SEM images, precipitates were formed after acid etching which were removed after surface cleaning methods. Although HF acid etching makes the ceramic surface irregular, creating an empty space shape and three-dimensional ducts, the process creates a precipitates layer on the ceramic surface which interferes in bond strength. SEM images analysis showed that ultrasonic bath made visible the three-dimensional pores, removing formed precipitates [11]. For lithium disilicate ceramics, HF acid etching during $20 \mathrm{~s}$ can induce corrosion of the glassy matrix creating highly retentive topography letting lithium disilicate crystals intact. When ceramic surface was not cleaned, sparse residues were formed in the gaps that glassy matrix was dissolved. After cleaning ceramic surface by air-water spray method or by ultrasonic cleaning method, residues and precipitates were eliminated [10].

Compared to air-water spray, ultrasonic bath can generate higher statistically significant values for bond strength between cement and ceramic, because post-etching precipitates were better removed by ultrasonic bath. This can be confirmed because measurements made by energy dispersive $\mathrm{x}$-ray spectroscopy (EDS) have indicated that F- was not removed completely with air-water spray [12]. Through the observance of SEM images, in the present data, the specimens which received ultrasonic bath showed lower level of acid precipitates on the ceramic surface compared to non-washed specimens, but it did not increase the flexural strength and surface roughness.

The incorporation of neutralization with supersaturated solution of sodium bicarbonate attempted to limit HF effect on the ceramic surface, creating a regular and uniform etching pattern, decreasing the weakness of the ceramic microstructure caused by the selective, nevertheless, extreme removal of glassy matrix. Sodium bicarbonate is a salt that reacts with HF and neutralizes its effect, limiting its action. The neutralization process influenced in bond strength values between feldspathic ceramic and resin cement. After neutralization, ultrasonic bath removed the precipitates, contributing positively to the bond with resin [5]. Despite of this fact, in the present data, the neutralization method did not influence positively the results for flexural strength, contact angle and surface roughness.

SEM images showed acid precipitates formed after surface etching, but, post-etching methods proposed in the data had eliminated them, though, no statistically significant difference to flexural strength and to surface roughness was observed. However, contact angle decreased after acid etching with $\mathrm{HF}$ compared to control group, being HF group the lowest value for contact angle. This can indicate the ceramic does not need post-etching cleaning when related to wetting property, once the contact angle property can be an indicator of total surface energy and wettability [18]. This finding can be also found in other study [15], which non etched specimens had higher contact angle compared to etched specimens which had the lowest contact angle, and so, higher wetting. Cleaning methods decreased the wetting compared to etched samples in other studies [15]. The present data noticed that acid etching with HF decreased contact angle compared to control group, increasing wetting for lithium disilicate ceramics.

A study showed that flexural strength decreased after surface etching with HF for feldspathic ceramic [19], which did not happen in the present data. However, other study reached the same results of the present data. This study showed no statistically significant difference between the control group and HF acid etched groups for flexural strength, for the feldspathic ceramic and for castable glass ceramic [20]. This could happen because of the microstructure and the ceramic composition, factors that control the dissemination of mechanical microretentions produced by acid etching with HF [21].

Although acid etching with HF does not increase flexural strength and surface roughness, it is still important for increasing the wetting of the ceramic surface. Acid etching method 
generates visible precipitates in SEM images, however, their elimination does not change surface topography concerning to surface roughness.

\section{CONCLUSION}

It can be concluded that HF did not decrease the mechanical strength of the lithium disilicate ceramic. Post-etching surface treatments did not increase the mechanic strength of this ceramic. Acid precipitates formed by $\mathrm{HF}$ acid etching were removed after surface cleaning methods, but did not increase the average roughness of this ceramic. The contact angle was reduced after surface treatments, showing an increased wettability especially in the HF group.

\section{REFERENCES}

1. Shenoy A, Shenoy N. Dental ceramics: an update. J Conserv Dent. 2010 OctDec;13(4):195-203.

2. Liu PR. A panorama of dental CAD/CAM restorative systems. Compend Contin Educ Dent. 2005 Jul;26(7):507-8,10,12 passim; quiz 17,27.

3. Jardel V, Degrange M, Picard B, Derrien G. Correlation of topography to bond strength of etched ceramic. Int J Prosthodont 1999;12:59-64.

4. Addison 0,Marquis PM, Fleming GJ. Resin strengthening of dental ceramicsthe impact of surface texture and silane.J Dent. 2007 May;35(5):416-24.

5. Saavedra G, ArikiEK, Federico CD, Galhano G, Zamboni S, Baldissara P, etal. Effect of acid neutralization and mechanical cycling on the microtensile bond strength of glass-ceramic inlays Oper Dent. 2009 Mar-Apr;34(2):211-6. doi: 10.2341/08-68.

6. Stewart GP, Jain P, Hodges J. Shear bond strength of resin cements to both ceramic and dentin. J Prosthet Dent. 2002 Sep;88(3):277-84.

7. Peumans M, Van Meerbeek B, Yoshida Y,Lambrechts P, Vanherle G. Porcelain veneers bonded to tooth structure: an ultra-morphological FE-SEM examination of the adhesive interface. Dent mater. 1999;15(2):105-19.
8. Magne P,Cascione D. Influence of post-etching cleaning and connecting porcelain on the microtensile bond strength of composite resin to feldspathic porcelain. J Prosthet Dent. 2006 Nov;96(5):354-61.

9. Aida M, Hayakawa T,Mizukawa K. Adhesion of composite to porcelain with various surface conditions. J Prosthet Dent. 1995 May;73(5):464-70.

10. Belli R, Guimaraes JC, Filho AM, Vieira LC. Post-etching cleaning and resin/ ceramic bonding: microtensile bond strength and EDX analysis. J Adhes Dent. 2010 Aug;:12(4):295-303.

11. Canay S, Hersek N, Ertan A. Effect of different acid treatments on a porcelain surface. J Oral Rehabil. 2001Jan;28(1):95-101.

12. Martins ME, Leite FP, Queiroz JR, Vanderlei AD, Reskalla HN, Ozcan M. Does the ultrasonic cleaning medium affect the adhesion of resin cement to feldspathic ceramic? J Adhes Dent.2012 Dec;14(6):507-9.

13. Demir N, Subasi MG, Ozturk AN. Surface roughness and morphologic changes of zirconia following different surface treatments. Photomed Laser Surg. 2012 Jun;30(6):339-45. doi: 10.1089/pho.2011.3213.

14. Strasser T,Preis $V$, Behr M, Rosentritt M. Roughness, surface energy, and superficial damages of CAD/CAM materials after surface treatment. Clin Oral Invest. 2018 Nov;22(8):2787-2797. doi: 10.1007/s00784-018-2365-6.

15. Amaral $R, O z c a n M, B o t t i n o ~ M A$, Valandro LF. Resin bonding to a feldspar ceramic after different ceramic surface conditioning methods: evaluation of contact angle, surface $\mathrm{pH}$, and microtensile bond strength durability. J Adhes Dent. 2011Dec;3(6):551-60. doi:10.3290/j.jad.a19815..

16. Ramakrishnaiah R, Alkheraif A, Divakar D, Matinlinna J, Vallittu P. The Effect of Hydrofluoric Acid Etching Duration on the Surface Micromorphology, Roughness, and Wettability of Dental Ceramics. Int J Mol Sci. 2016 May 27;17(6). pii: E822. doi:10.3390/jims17060822.

17. Albakry M, Guazzato M, Swain MV. Biaxial flexural strength, elastic moduli, and $x$-ray diffraction characterization of three pressable all-ceramic materials. J Prosthet Dent. 2003 Apr;89(4):374-80.

18. Zisman WA. Relation of the equilibrium contact angle to liquid and solid constitution. Advan Chem Ser. 1964; 43:1-51.

19. Baez R, Blackman R. Glazing inside surface of castable ceramic crown segments to improve strength. J Dent Res. 1988 Jun; 378.

20. Yen TW, Blackman RB, Baez RJ. Effect of acid etching on the flexural strength of a feldspathic porcelain and a castable glass ceramic. J Prosthet Dent. 1993 Sep;70(3):224-33.

21. Della Bona A, Anusavice KJ, Hood JA. Effect of ceramic surface treatment on tensile bond strength to a resin cement. Int J Prosthodont. 2002 MayJun;15(3):248-53.

\section{Natália Rivoli Rossi}

(Corresponding address)

Institute of Science and Technology

UNESP - Univ Estadual Paulista, São José dos Campos

Av. Dr. Francisco José Longo, 777, São Dimas, São José dos Campos, Brazil

Date submitted: 2018 0ct 22

e-mail: ntlrossi@hotmail.com
Accept submission: 2019 Mar 12 